\title{
Reflections on our second English number of 2016
}

Since the beginning of 2015, our review has from time to time been issued in English, as well. As international sciences mainly use English for communication, Opus et Educatio has been striving to offer a quality framework for domestic authors on one hand and the authors willing to appear in the Hungarian publication field on the other. Of course, in this case, too, the previous judgement and reading of the papers is a basic condition. This year, we have made great steps forward: our online digital issue has been transferred to the interface of the Open Journal System, and besides, in harmony with the growing number of the articles, we are now issuing the second foreign language number of this year. It is also pleasing that, stepping into the third volume of this review, is is exactly this issue that surpasses the border (300 characters which is app. 7.5 sheets) that indicates the impact of willingness to publish and of thematic development.

Of course, in this number, as well, we have made efforts to strengthen thematic features. In case we wish to demonstrate the connection between the articles published, we can say that, implicitly, the basic dimension is the development if higher education. Under the heading Studies, the papers by a Brazilian researcher, Marilia Ramos and Hungarian authors - Enikö Baróthi, Attila Mészáros and Dániel Gergö Pintér - analyse the cultural embedment of higher education and possibilities of its international comparison and within that the special role played by teacher training in this system. Main Topic, offering a newish formal frame, connects to this bloc. It introduces the lectures presented during the scientific symposium titled Co-creative problem solving and organized together by the Budapest University of Technology and Economics and the Tampere University of Applied Sciences in May this year. The Finnish speakers - Pirjo Jaakkola who is an author of our review and his colleagues: Päivi Karttunen and Sami Suhonen - and our Hungarian colleagues playing an important role in inter-institutional cooperation: György Magyar, Anikó Kálmán and Judit Reményi present innovation processes the higher education importance of which lean beyond the direct and successful cooperation of the two institutions. All this is particularly interesting, and proved with evidences when necessary, in the series of reports some elements of which have already been published in our review, and the core objective of which is to summarize the experiences gained by the participants and leaders of teachers' domestic professional further education during their search and study of the Finnish education system. With their analysis adopting several professional standpoints, Zsolt Csutak and Lászlóné Nagy-Czirok lend a colourful, and not dark, tone to the valuable materials of the symposium. All this, in the selection containing nine papers, give an undoubtedly special character to this number.

We carry on with the section titled Projects which offers information on the Open Content Development (OCD) project that supports a methodological innovation in VET and teacher training during a period of four years and is implemented within the frames of the Methodological Tender Call announced by the Hungarian Academy of Sciences. Since the project adopts openness not only in its title but also in the whole development process, we have great hopes that the report on the start of the project will generate further interest and 
partnership. During research and development, it is a basic task to create the active partner participation of the VET partner institutions and their teachers in the first phase of the project (2016-2018) in the indicated VET institutions undertaking professional collaboration.

This number of the review, too, is finished with a recension. Thematic feature is also indicated by the fact that the book by Anikó Kálmán, titled Learning - in the New Lifelong and Lifewide Perspectives and published in Tampere is introduced by Marc Groossens, an internationally acknowledged researcher; this reminds us that LLL is a real global phenomenon, and the good practices introduced demonstrate this tendency.

Finally, this is the sixth number of this year, two of them published in English. These facts show an inter-connection of development which we highlight because in the future we wish to publish more and more numbers and more and more of them in English. In addition to the usual Christmas wishes, we would respectfully like to say: in accordance with the severalcenturies traditions of our University, our Editorial Board is continuously engaged with quality, and intends to meet the requirements of scientificity at the highest possible level while keeping the basic norms of providing information in sight. We welcome Readers' feedbacks as well as interesting and valuable articles in English so that our review can join the international scientific flow of information more and more deeply.

Our Editorial Board wish our Readers Merry Christmas and a Happy New Year!

Budapest, December 2016.

András BENEDEK

Chief Editor

of Opus et Educatio 